\title{
European Language Portfolio as an Effective Tool of Assessment Used in Teaching a Foreign Language
}

\author{
Vita V. Vonog* \\ Siberian Federal University \\ 79 Svobodny, Krasnoyarsk, 660041, Russia
}

Received 24.09.2018, received in revised form 26.09.2018, accepted 08.10.2018

The article is devoted to the description of the main functions and descriptors of the European Language Portfolio (ELP) in teaching a professional foreign language to students of engineering profile within learner-centred education. The author describes the algorithm of the studying results assessment. Moreover the article considers the ELP structure and its content as well as positive experience of testing this technology in teaching students of a Higher School. The ELP piloting has become particularly relevant in the framework of the arrangements for training students of engineering profile to proficiency in English in accordance with the internationally recognized system in terms of improving the competitiveness of the leading Russian universities, implemented in Siberian Federal University (Krasnoyarsk).

The author describes a methodological basis for designing an assessment system corresponding to the specific character of engineering education, specifies the main functions of new tools of assessment and defines the peculiarities of that activity due to the ELP. The article deals with explaining the use of the European Language Portfolio with emphasis on a learning individual's educational content.

Results include monitoring the performance obtained in the teaching process, author's observations and research based on students' outcomes and aimed at monitoring the development of their own perspective due to the ELP piloting by the department of foreign languages for engineering of School of Philology and Language Communication of Siberian Federal University.

Conclusions were confirmed by prognostic simulation and experimental learning. According to author's point of view, the ELP is based on principles which tend to challenge traditional learning and teaching practices and thus impact on education policy and systems. On the other hand, piloting this technology outlined a perspective range of problems to be addressed in further research concerning engineering education.

Keywords: European Language Portfolio, assessment, engineering education, intercultural foreign language professional communicative competence, foreign language teaching.

Research area: language education, education science.

(C) Siberian Federal University. All rights reserved

* Corresponding author E-mail address: vonog_vita@mail.ru

This work is licensed under a Creative Commons Attribution-NonCommercial 4.0 International License (CC BY-NC 4.0). 
Citation: Vonog, V.V. (2018). European language portfolio as an effective tool of assessment used in teaching a foreign language. J. Sib. Fed. Univ. Humanit. soc. sci., 11(10), 1711-1728. DOI: $10.17516 / 1997-1370-0328$.

\section{Introduction}

Nowadays the increase of cross-cultural communication caused the grow of the number of collaborations in the educational environment of universities. The subject of cooperative study are engineering topics, construction, engineering. There are a number of important requirements for specialists in these areas: highly developed communicative competence, the availability of organizational skills, the ability to work in a team, and "the value-semantic attitude to professional activity is formed under the influence of the global context of the development of the profession, taking into account world trends, the experience of others countries and peoples in the studied subject area" (Yarotskaya, 2015: 51).

In connection with this, the modern higher school faces a difficult task: to create conditions for the future specialist of a non-language profile for successful educational and professional and as a result professional activities. This point of view is supported by other scientists who believe that a modern technical University must train professionals who apart from having a high special competence, also have the understanding of the common cultural issues. (Sergeyeva, Voskrekasenko, 2016: 485). Due to globalization, higher education internationalization, student exchange programs and academic mobility and international projects students and academics tend to search for new ways of studying and teaching English language as means of academic and professional communication. The possibility comes true through redesign of the academic units (Cheah, Chen, Ting, 2005: 105) in teaching the subject "Foreign language" and balanced forms of learning and forms of assessment. In spite of being unsatisfied with graduates' competences of engineering specialties, business doesn't tend to think about changes that universities might implement to improve the situation (Vcherashniy et al., 2016: 15).

There are many technologies that are actively introduced by higher school teachers in the educational process: the technology of distance learning using blended learning (Sysoev, Evstigneeva, Evstigneev, 2015; Polat, 2010; Yevdokimova, 2007; Vonog, Prokhorova, 2015; Titova, 2017; Galustyan, 2017), e-portfolio technology (Smolyaninova, 2016; Koryakovtseva, 2010; Kohonen, 2003; Schärer, 2004), the foreign language profile of profession (Yarotskaya, 2015; Vonog, Yarotskaya, 2018), modular 
training (Filonchik, Ryzhova, Kokorina, 2018), case-study (Khomyakova, 2011). Among advantages the authors define the taxonomy of students achievements obtained in the educational activity which allows to track the process of learning outcomes; a possibility of individual approach used in a group training. It doesn't take a lot of time to define the level of proficiency in a foreign language, to monitor dynamics of factors by means of analyzing the achievements and gaps bridging compensation.

In our paper we focus our attention on the technology that has been originated from Western pedagogy and called language portfolio. This technology was proposed in terms of the framework of the Council of Europe project (Schärer, 2004), and then it was adapted in different countries in accordance with cultural and national characteristics (Vonog et al., 2016: 132).

The language portfolio can be defined as "... a flexible educational tool that can be adapted to almost any learning situation, depending on the purpose of instruction, the age of the trainees, the stage of language proficiency, the learning conditions, the individual style of the learning activity, and the methods and means of instruction" (Koryakovtseva, 2010: 143).

In terms of searching for an appropriate means of assessment aimed at meeting the needs of students of engineering specialties, European Language Portfolio has been in the focus of pedagogical interest for a few years. It is not only that any attempt to establish levels of proficiency is to some extent arbitrary, and adopted levels should be adequate to show progression in different sectors (but should in any particular context not exceed the number of levels between which people are capable of making reasonably consistent distinctions), the matter is that a common framework should be context-free (generalisable) and context-relevant (transferable) at the same time; it should be based on present-day theories of language competence, and be accessible to practitioners (Common European Framework..., 2001). Moreover, those levels only reflect a vertical dimension and take only limited account of the fact that learning a language is a matter of horizontal as well as vertical progress (Common European Framework..., 2001).

Heterogeneity of professional needs in specific professional fields adds to the variety of determining factors and makes any single model, that we seek to construct, too general to be an efficient educational instrument applicable to all particular contexts. Thus, a possible way out is to start with a model specific to one professional domain.

Common European Framework of Reference for Languages alone may be sufficient to satisfy users and learners of language who have other than language- 
related tasks to accomplish. This article presents the author's observations how to use the European Language Portfolio (the ELP) in teaching a foreign language. The data collected in a series of specially conducted experiments show that this approach results in increasing students' motivation and interest, improving their self-study abilities as well as achieving practical goals set in the syllabus.

The underlying idea of the approach is that students should not get anything ready-made. They should understand exactly what they are doing and why, and what other things they have to do to achieve the aims they pursue - they actually choose to pursue - in learning a foreign language and cross-cultural understanding.

The ELP meant for general purposes was used by groups of students of engineering specialties as a sort of reference book to help them devise the foreign language profile of their profession and elaborate it in the course of their study at the university and, hopefully, further on - in a life-long perspective.

\section{Theoretical Framework}

In teaching foreign languages to non-linguistics students, along with the above tendencies, growing attention is given to systemically assessing overall intercultural foreign language professional communicative competence (IFLPCC) (Byram, 1997; Khomyakova, 2011; Vonog, 2017; Yarotskaya, 2016, etc.) and its individual aspects, namely to testing linguistic competence (Bachman, 1990; Pavlova, 2003), professionoriented oral foreign language skills (Galustyan, 2010), self-assessment (Little, 1991; Scharer, 2005, 2006, 2007; Sysoev, Evstigneeva, Evstigneev, 2015; Richterich, Schneider, 1992; Galskova, 2000) as well as to computer testing (Bejar, 1980) and mobile assessment means (Titova, 2017; Volegzhanina, Chusovlyanova, Adolf, Bykadorova, Belova, 2017). Among conclusions particularly relevant to our research are those concerning the use of profession-oriented situations and students' creative work (Smolyaninova, 2016; Khomyakova, 2011; Yarotskaya, 2016; Yevdokimova, 2007) as instruments of assessing IFLPCC. Promising results were obtained in connection with alternative methods of evaluation in teaching foreign languages to students of engineering majors (Matienko, 2009; Vonog, 2016), flexible evaluation criteria to differentiate between $\mathrm{C} 1$ and $\mathrm{C} 2$ profession-oriented levels of the European Language Portfolio (Yarotskaya, 2013), as well as to a new productive-learning-activity approach to pedagogical guidance and specifically to the assessment of foreign language vocational training outcomes (Vonog and Yarotskaya, 2017; Ilina, 2016; Yarotskaya, 2016). 
Foreign authors' research of the problems in question of assessment (Alderson, 1995; Anderson, 2001; Bachman, 1990, 1996, 2002; Burgess, Head, 2006; Bond, 1996; Brian, 2005; Byram, 1997; Douglas, 2010; Kohonen, 2003; Scharer, 2005, 2006, 2007; Spolsky, 1975; Weir, 1995, 2005 and others) mostly focuses on similar educational topics, which confirms the general trend in the development of pedagogical assessment tools.

Analysis of recent research devoted to ELP shows that the idea of a European Language Portfolio was introduced at a Council of Europe symposium in 1991. According to Schärer, 'the ELP promotes a learner-centered, communicative and inclusive approach to language learning in a lifelong perspective; yet formal education is organized into sectors with more or less selective transfer points. The ELP is designed to promote plurilingualism, intercultural competence and mobility" (Schärer, 2015: 28). This is one of the reasons why the ELP was piloted in many countries and became a popular pedagogical tool among teachers and students.

Thus, discussing and evaluating the Finnish pilot project (1998-2001), V. Kohonen (Kohonen, 2007) reports that the ELP provides an important interface between learning, teaching and assessment; motivates and enables learners to gradually take more responsibility for their own learning; produces "invisible learning outcomes" such as tolerance of ambiguity and uncertainty in communicative situations, and learning skills and strategies necessary for continuous, independent language learning" (Schärer, 2015: 38).

Describing the ELP pilot project in Czech primary and lower-secondary schools R. Perclova (Perclova, 2006; 218-220) focuses on teacher and learner beliefs and attitudes and relates her findings to key issues of innovation and collective ELP use. She argues that in order to achieve success in language and intercultural learning and to develop the ability gradually to take ownership of one's learning the following factors are of key importance: learner confidence and motivation; the creation of a rich positive environment and a wide variety of opportunities; frequent practice; and the ability to evaluate one's own work. In a qualitative empirical evaluation of working with the ELP in Irish post-primary schools, Ushioda and Ridley (Ushioda, Ridley, 2002: 12) report that the success or effectiveness of the ELP as a pedagogical tool must be gauged with reference to the particular teaching-learning context in which it is implemented, and validated in relation to the evolving experiences of those engaged in working with it.

According to Schärer, given the encouraging impact of the ELP on individual learning processes and learning outcomes, it could be assumed that the shift from 
individual to collective use would be a smooth, unproblematic process (Schärer, 2015: 38). Yet moving from individual use in voluntary groups to collective use that is recommended or compulsory for whole educational institutions, can have far-reaching consequences. Educational authorities and teachers deciding how to make collective use of the ELP may be faced with a dilemma. Recommended use seems to be in line with the principle of learner ownership, but might split a group into users and nonusers, leading to undue problems in the use of the ELP and a potential loss of benefits; while compulsory use may be beneficial for all learners but seems to be in conflict with the concept of learner ownership and may provoke resistance.

According to research review, the analysis of the language portfolio application in practice have revealed its necessity and importance as a means of assessment used to define the quality of language training of students of engineering profile (Safronenko, 2013); the language portfolio turned out to be an indicator of professional language competences used in the process of teaching a foreign language to students of engineering profile in higher schools (Miroshnikova, 2008); the language portfolio is the tool aimed at developing a socio cultural competence of students (Ivanova, 2003); and the ELP can act as the tool of assessment and self-assessment of pupils' learning outcomes (Galskova, 2000).

According to N. Koryakovtseva (Koryakovtseva, 2010: 144), one of the important advantages of the language portfolio is the possibility for the student to trace independently the dynamics of his level of knowledge of the language being studied for a certain period of time and to reflect the peculiar biography of his linguistic and speech development. In the process of independent work, the student, through reflexive self-esteem, can reflect his abilities, abilities, progress in studying language and culture, reveal and show his abilities as a developing linguistic personality. However, at the same time L. Yarotskaya considers the ELP as a complementary tool that can be used in combination with other pedagogical tools. Common European Framework of Reference for Languages alone is not sufficient to satisfy users and learners of language who have other than language-related tasks to accomplish. L. Yarotskaya suggests bridging the gap using the European Language Portfolio (the ELP) in combination with another highly efficient collective tool to be worked out on the basis of the ELP by students themselves - the Foreign Language Profile of their profession (Yarotskaya, 2013: 134).

It should be noted that all authors consider the ELP as an effective tool used for motivating students to learn foreign languages in terms of life-long perspective. It may 
be explained by the fact that the professional focused language portfolio increases the importance of foreign language skills for students of nonlinguistic profile, and thanks to the available descriptors which are directly connected with future engineering activity of the student show the prospects of the practical use of the language competences in real-life autonomy. The experience of the ELP use in the educational process has been digested by the author of this article to propose a productive assessment theory adequate to effectively guide the learner-centered process of developing IFLPCC obtained by non-linguistics students.

\section{Methods}

The European language portfolio was designed, first of all, for the student to be able to evaluate their language competencies by means of method of reflection, which means to look into themselves, to receive an answer to the question about their abilities, the results of their educational and cognitive activity, to identify and understand progress in learning a foreign language, as well as the culture of the language being studied. In turn, the teacher should appreciate and encourage the students' desire for self-education and help them achieve their goals and tasks independently (by students) and in cooperation (students and teachers together), however a regular feedback (the availability of evaluation sheets and teacher's comments concerning students work) should be put into practice.

The ELP consists of three parts: a passport, a language biography and a dossier. In the first part, so-called, passport, we can find information about a student, a brief overview of their achievements in studying and mastering a foreign language, attending language courses and their international contacts. It provides an overview of the language competences at a given moment, defined in terms of skills and the common reference levels; it includes a self-evaluation grid, and records formal qualifications and certification. It provides personal history of the owner's language learning experience and progress. It includes information on linguistic and cultural experiences in and outside class; self-assessment checklists, describes the basic communicative competences.

In the second part, so-called language biography, all communicative competences of the student are presented and described. The levels referred to in the European Language portfolio are those of the European Framework of References for Languages. Students can measure their command of English by saying what they can do in various skill areas. These statements for general overall ability (giving six levels from A1- 
C2), give students clear statements of ability against which to measure themselves. In most groups of Siberian Federal University students of non-linguistic specialties, the command of English corresponds to A2 / B1. It means that in listening and speaking our students are able to express simple opinions or requirements in a familiar context. In reading they are able to understand straightforward information within a familiar area. In writing students are able to complete forms and write short and simple letters and postcards.

The first stage, the language biography is aimed at filling each new topic of the practical lesson gradually in the process of learning. Before each theme the teacher looks through the materials offered by the educational and methodical recourses, and sets the students' goals for obtaining knowledge and skills. For example, for students of transport specialties in terms of the topic 'Under the bonnet' such tasks can be applied at the level of language competence.

In vocabulary: mastering new terminology, used to assemble engine parts; prepositions of location - to describe the position of the parts relative to each other; Searching for potential glossary by mastering the relevant set of derivative suffixes (e.g. to maintain-maintenance), the ability to make interrogative sentences; In listening and reading possible tasks may be understanding the text describing the main characteristics of the car. In speaking the following abilities may be assessed: to make up a dialogue about the main characteristics of the car or to present information on the principles of the internal combustion engine properly. In writing the ability to state information about the principles of the internal combustion engine in a letter may be taken into consideration.

The listed tasks, methods and results of their implementation are fixed in the portfolio, including the glossary, texts, grammatical exercises, tests, etc. In order to achieve a particular goal, students can complete this section with their own materials. Also this part may include diagnostic tools by means of which each student can determine a command of language proficiency or developing IFLPCC. At the end of each topic students usually give their feedback. Students formulate their achievements by means of phrases like 'I can ...', 'I know ..., or answers to questions 'What can I say about ...?', 'What do I know about ...?' etc. Thanks to this portfolio structure, a teacher can monitor the learning process of each individual student, give individual recommendations on issues that are still problematic for a particular student, and also check with the help of additional tasks and questions whether the material is well understood. 
In the third part, so-called dossier, there are creative, design works, compositions, final test works of students, as well as certificates and diplomas confirming their active participation in international and scientific communities, conferences, etc., and, of course, plans and a roadmap for further study of a foreign language.

With a deep analysis of the structure and content of the European language portfolio, it can be stated with accuracy that it is an effective tool for assessing the learner's language competence. In addition, the introduction of the language portfolio into the system of education will be of practical importance both for the teacher and for the student; the language portfolio will serve as an understandable and accessible tool for the learner, by means of which he or she can easily determine the level of foreign language proficiency, analyze their achievements and the gaps that he needs to fill in order to improve their skills. All this will allow the student to assess their knowledge, skills and competences (e.g. intercultural foreign language professional communicative competence) in learning a foreign language, and will also contribute to increasing motivation and will allow him to strategically determine further self-development, which will ensure the graduate of an engineering university mobility and competitiveness in the international labor market.

\section{Results}

Let us consider in more detail the components and practical significance of the language portfolio, which was approved by the department of foreign languages for engineering of the School of Philology and Language Communications of the Siberian Federal University. My SFU (Siberian Federal University) service allows students to record their achievements and view the achievements of other users in the following categories: 1. Science (Participation in research projects (grant, project); 2. Publications in scientific journals; scientific monographs; 3. Sport (participation in sports competition); 4. Qualifications (knowledge of foreign languages, additional professional qualifications); 5. Postgraduate studies (postgraduate attestation sheet (for graduate students), candidate exams, intermediate certification); 6. Educational process (course projects and works, reports, internship, essays and abstracts).

The data collected in a series of specially conducted experiments, with the total number of participants reaching 56 persons, definitely show that this approach to productive assessment leads to increasing students' motivation and interest, improving their self-study abilities, developing their professional identity, as well as achieving practical goals set in the syllabus with top results. All the students that took part in experimental teaching-and-learning passed exams in English successfully. 
It goes without saying that we specified the foreign language skills and relevant levels of culture awareness to a first approximation only because at that stage the students were not prepared for more, and for us it is a matter of principle and high priority not to bore students with anything they do not quite understand. It is also very important to show to them that that we do rely on their initiative. Of course, we have our pedagogical understanding of things - of what should be done and how - that is why all discussions should be arranged in such a way as to guide them towards some form of a pedagogically sound compromise.

All the while, the students were encouraged to refer to the ELP to assess the level of their foreign language communicative competence to see what distance they had to go to achieve their aims. Thus, we had the starting point, which was approximately A2 plus.

The educational procedure involved the following stages. At first 37 students of Institute of engineering physics and radio electronics (major: nuclear physics and technology) were to prepare presentations in accordance with the module titled 'Jobs' of syllabus "Foreign language". Their presentations included a wide range of topics including Future of Nuclear Energy, Nuclear Weapon, Types Of Energy, Liquid Crystal and so on. The department of foreign languages for engineering developed several criteria according to which the students were assessed. The results of presented reports were awarded to taking an exam in English. The following criteria are presented in Table 1.

The teacher summed up the total number of scores obtained by a student for presentations done. At the end of the project according to results the teacher had to write a feedback and sign it. After that students attached this document to SFU achievements service to prove that the work had been done successfully. As a result 36 students passed their exams in English, one student failed as he obtained 2.5 scores.

Besides, in terms of the project 19 students of Polytechnic Institute took part. Due to exam requirements of the course "English for specific purposes" they were to translate 15000 symbols of original text concerning their dissertation's subject matter. Their works have been assessed according to the following criteria: accuracy of the meaning of the original text in translation; the use of proper language tools (lexical and grammatical); the use of proper register of the original text; completeness. According to results 13 students were assessed with "Excellent" marks. 6 students were assessed with "Good" marks. Students completed their portfolios with new achievements convinced by teacher's comments. This section creates a real picture of the level of 
Table 1. Criteria used to assess a presentation

\begin{tabular}{|l|c|}
\hline \multicolumn{1}{|c|}{ The structure of the presentation } & $\begin{array}{c}\text { The maximum } \\
\text { number of scores }\end{array}$ \\
\hline Content & \\
\hline The purpose of the work is formulated & 0,5 \\
\hline The tasks and the course of work are comprehensible & 0,5 \\
\hline The information is presented fully and clearly & 0,5 \\
\hline Availability of illustrations (visuals) & 0,5 \\
\hline Conclusions have been drawn & 0,5 \\
\hline Presentation design & 0,5 \\
\hline The total look of design & 0,5 \\
\hline the text presented is comprehensible and clear & 0,5 \\
\hline $\begin{array}{l}\text { All font parameters are well matched, the font size is the optimal and it is the } \\
\text { same for all slides }\end{array}$ & 0,5 \\
\hline Key word have been highlighted & \\
\hline Presentation's effect & 0,5 \\
\hline General impression & 5 \\
\hline Maximum quantity of scores & $3-5$ scores \\
\hline Final assessment: & Less than 3 scores \\
\hline "pass" & \multicolumn{2}{|c|}{} \\
\hline "fail" & \\
\hline
\end{tabular}

development of the students intercultural foreign language professional communicative competence. Moreover the public presentation in this section can be considered as an attestation work and may be a taken as a part of an exam.

\section{Discussion}

To solve and overcome the problems and contradictions that we talked about and the successful implementation of the implementation of the language portfolio, it is necessary to remember the following. First of all, it is necessary to solve the problem of the complete interrelation and work of departments of foreign languages with graduate chairs in order to create the language portfolio that meets requirements of a potential employer. It seems quite beneficial from the point of developing appropriate vocational, professional and language competencies of students of engineering profile. As an example, it is proposed to create an interdisciplinary commission at the faculty, which would include teachers of the department of foreign languages and graduate chairs, which will help determine the portrait of a graduate of an engineering university and determine an individual educational trajectory on which further education of the student will be based; 
- the next step can be the creation of such models that will be focused on a specific specialty, but taking into account the competence approach and the principles of pragmatic didactics;

- accordingly, it is necessary to develop criteria for assessing the vocational and language competencies of students, taking into account the multilevel education system.

According to author's research and observations the teachers may face the following problems when introducing the European language portfolio into the higher school classes.

First of all, difficulties can arise with the organization of independent work, since both teachers and students are limited by the number of hours stated in terms of discipline "Foreign language" in the curriculum of a Higher school, even attempts of certain universities to combine on-line courses and face-to-face classes do not ensure full compliance with the technology of the language portfolio. Moreover, considerable attention is also drawn to the fact that higher schools do not receive social orders from employers, so universities are forced to work focusing only on the standards described in educational standards. This leads to the absence of a practice-oriented model that is mandatory in the language portfolio and does not provide an opportunity to set the goal of training specialists of engineering universities appropriately by means of a professional foreign language. Since, at each level of the multi-level education system, it is necessary to create such a system for assessing vocational linguistic competencies, which would correspond to each individual profession. Finally, the problems are connected with the fact that many teachers with extensive experience have stereotypes of traditional professional and pedagogical thinking, which in turn hinders awareness of the need and acceptance of new educational realities that require a complete restructuring and modernization of traditional systems of teaching a foreign language.

\section{Conclusion}

The development and implementation of the language portfolio in the higher school is relevant today, since the main emphasis is put student's autonomy, which is necessary for university of engineering profile. The work and analysis of the language portfolio allows both the teacher and the student to see intermediate and final results of their efforts and achievements, which is not possible with the existing assessment system. As an advantage, we also note the existing package of working materials that the student can use in their future professional work. We should also take into account 
that the language portfolio is a student's passport, which reflects all the student's achievements and experience, which will be an indicator of his or her effective scientific and educational activities, and from the point of view of methodology it also provides a person-oriented approach to teaching a professional foreign language in a higher school. However, as a drawback we may name a lack of validity and reliability of self-assessment as students sometimes fail to gauge their linguistic competences adequately. Reporting may be a serious challenge and as a result teachers need to have regular assessment in a classroom as well as systematic guidance.

Working with a language portfolio means creating a number of conditions for its successful implementation and introduction into the system of a higher professional education, namely: participation in international scientific and practical conferences, competitions in a foreign language; the need to create conditions for data processing and self-assessment of their knowledge.

Teachers constantly talk about the need to increase the motivation of students, we believe that the language portfolio is an effective tool to solve this problem, since: when working with its results, the student realizes the importance of a foreign language professional competence and the need for its improvement; it provides the learner with the right to monitor and assess the level of their competences and set goals and objectives for achieving them; contributes to the development of students' ability to learn a foreign language in the professional domain independently.

\section{References}

Bachman, L. (1990). Fundamental Considerations in Language Testing. Oxford: Oxford University Press.

Byram, M. (1997). Teaching and Assessing Intercultural Communicative Competence. Clevedon: Multilingual Matters.

Cheah, Ch.Y.J., Chen, P.H., Ting, S.K. (2005). Globalization challenges, legacies, and civil engineering curriculum reform. In Journal of Professional Issues in Engineering Education and Practice, 131 (2), 105-110.

Common European Framework of Reference for Languages: Learning, Teaching, Assessment (2001). Cambridge: Cambridge University Press.

Galskova, N.D. (2000). Yazykovoy portfel kak instrument otsenki i samootsenki uchashchikhsya v oblasti izucheniya inostrannykh yazykov [Language portfolio as the tool of assessment and self-assessment of pupils in the field of a learning of foreign languages]. In Inostranyye yazyki v shkole [Foreign languages at school], 5, 6-11. 
Galustyan, O.V. (2010). Otsenivaniye inoyazychnoi kommunikativnoi kompetentsii studentov neyazykovogo vuza v kontekste Bolonskogo protsesa [Assessment of foreign communicative competence of non-linguistics higher school students in terms of Bolonskii process]. In Aktual'nye voprosy sovremennogo universitetskogo obrazovaniya [Topical issues of modern university education]. Proceedings of the 10th Russian-American research and practice conference. (pp. 255-257). Saint Petersburg.

Ilina, N.F., Petrova E.O. (2016). Kriterii gotovnosti studentov meditsinskogo vuza k professional'no-orientorovanomu inoyazychnomu obshcheniyu [Criteria of readiness of Medical Institute students for communication in English for professional use]. In Standarty $i$ monitoring $v$ obrazovanii [Standards and monitoring in education], 4(3), 20-24.

Ivanova, N.V. (2003). Language Portfolio as an Instrument for Student Development and Assessment, IN School in the 21 ${ }^{\text {st }}$ Century: Skillful Teaching-Successful Learning, Interregional Ural-Siberian TEA Alumni Conference, Novosibirsk, 32.

Khomyakova, N.P. (2011). Kontekstnaya model formirovaniya inoyazychnoi kommunikativnoi kompetentsii studentov neyazykovogo vuza (frantsuzskii yazyk) [Context model used for developing a foreign communicative competence of nonlinguistics higher school students (French language)]. (Unpublished doctoral dissertation). Moscow State Linguistic University, Moscow.

Kohonen, V. (2007). Student perspectives to the ELP: voices from the classrooms. Koskensalo A., Smeds J., Kaikkonen P. \& Kohonen V. (eds). Foreign languages and multicultural perspectives in the European contexts. Munster: LIT Verlag, 239-267.

Koryakovtseva N.F. (2010). Teoriya obucheniya inostrannym yazykam [The theory of teaching foreign languages]. In Produktivnye obrazovatelnye tekhnologii [Productive education technologies]. Moscow. Akademia, 192.

Koryakovtseva, N.F. (2010). Inostrannyi yazyk kak sredstvo gumanitarizatsii professionalnoy podgotovki sovremennogo spetsialista [Foreign language as a means of humanitarization of modern specialist professional training]. In Vestnik MSLU [Bulletin of Moscow state linguistic university], 1 (763), 33-43.

Little, D. (1991). Learner Autonomy. Dublin: Authentik.

Matienko, A.V. (2009). Alternativnyi control v obuchenii inostrannomu yazyku kak sredstvo povysheniya kachestva yazykovogo obrazovaniya [Alternative control used in teaching a foreign language as a means of improving a quality of language education]. (Unpublished doctoral dissertation). Tombov State University, Tombov.

Miroshnikova, O.Kh. (2008). Tekhnologiya professionalno-yazykovogo portfelya kak instrument obespecheniya kachestva $\mathrm{v}$ sisteme inoyazychnoy podgotovki $\mathrm{v}$ 
vysshey shkole [Technology of a professional and language portfolio as the tool of ensuring quality in the system of foreign-language training at a Higher school]. In Izvestiya RGPU [The news of RSPU named after A.I. Gertsen], 33 (73), 124-128.

Pavlova, I.P. (2003). O testovykh zadaniyakh, testakh i razlichnykh strategiyakh testirovaniya [On testing tasks, tests and different strategies of testing]. In Vestnik MSLU [Bulletin of Moscow State Linguistic University], 477, 146-159.

Perclova, R. (2006). The Implementation of European language Portfolio pedagogy in Czech primary and lower-secondary schools: beliefs and attitudes of pilot teachers and learners. Joensuu: University of Joensuu.

Polat, E.S. (2010). Sovremennie pedagogicheskie i informatsionnie tekhnologii $v$ sisteme obrazovaniya [Modern pedagogical and information technologies in the system of education]. Minsk: Akademiya.

Richterich, R. \& Schneider, G. (1992). Transparency and coherence: why and for whom? In North (Ed.), 43-50.

Safronenko OI. (2013). Problemy sovremennoy yazykovoy podgotovki v neyazykovykh vuzakh Rossiyskoy Federatsii [Problems of modern language training in non-linguistic higher schools of the Russian Federation]. In Izvestiya vuzov. Severo-Kavkazskiy region [News of higher education institutions. North Caucasus region], 6 (178), 115-118.

Sergeyeva, S.V., Voskrekasenko, O.A. (2016). Formirovanie sotsial'nykh kompetentnostei obuchaiushchikhsia $\mathrm{v}$ tekhnicheskom vuze kak mnogourovnevom obrazovatel'nom komplekse [The formation of students' social competences in a technical university as a multilevel educational complex]. In integratsiya obrazovaniya [Integration of Education], 20(4), 484-492. DOI:10.15507/19919468.085.020.201604.484-492.

Schärer, R. (2000). ELP Pilot project phase 1998-2000: Final report. Strasbourg: Council of Europe, (DHVT/EDU/LANG (2000) 31 rev.).

Schärer, R. (2009). European Language Portfolio: Final Report 2008. Executive summary.

Schärer, R. (2005, 2006, 2007). European Language Portfolio: Interim Report. Strasbourg: Council of Europe.

Schärer, R., David, L., Goullier, F. (2004). A European Language Portfolio: From piloting to implementation (2001-2004): Consolidated report. Strasbourg: Council of Europe.

Schärer, R. (2015). Revising the principles and functions of the European Language Portfolio with a focus on tertiary education. In Vestnik MSLU [Bulletin of Moscow state linguistic university], 14 (725), 28-47. 
Smolyaninova, O.G. (2016). Problema otsenivaniya obrazovatel'nykh dostizheniy: tekhnologiya e-portfolio. In Informatika i obrazovanie [Informatics and Education], $1(270), 55-63$.

Sysoev P.V., Evstigneeva I.A., Evstigneev M.N. (2015). The development of students' discourse skills via modern information and communication technologies. In Procedia - Social and Behavioral Sciences, 200, 114-121.

Titova S.V. (2017). Model mobilnosti obucheniya inostranym yazykam [The model of education mobility used for teaching foreign languages]. In Pedagogika $i$ psikhologiya obrazovaniya [Pedagogical and psychological studies of education], 1, $122-133$.

Ushioda, E., Ridley, J. (2002). Working with the European Language Portfolio in Irish post-primary schools: report on an evaluation project. Centre for Language and Communication Studies. Dublin: Trinity College Dublin.

Vcherashniy, P.M., Gafurova, N.V., Rumyantsev, M.V., Osipenko, O.A. (2016). Inzhenernoye obrazovaniye: smena formata. In Vyssheye obrazovaniye $v$ Rossii [Higher Education in Russia], 8-9 (204), 15-21. Available at: https://cyberleninka.ru/ article/n/inzhenernoe-obrazovanie-smena-formata

Volegzhanina, I.S., Chusovlyanova, S.V., Adolf, V.A., Bykadorova, E.S., Belova, E.N. (2017). Knowledge management as an approach to learning and instructing sector university students in post-soviet professional education. In Journal of Social Studies Educational Research, 8(2), 39-61.

Vonog, V.V. (2016). Alternativnye metody kontrolja v obuchenii inostrannym yazykam $\mathrm{v}$ ramkakh programy povyshenija konkurentosposobnosti veduschikh rosiiskikh universitetov (na primere sibirskogo federal'nogo universiteta [Alternative methods of evaluation in teaching foreign languages in terms of Russian academic excellence program (With Reference to Siberian Federal University)]. In Vestnik of Moscow state linguistic university [Bulletin of Moscow state linguistic university], 16 (755), 7-16.

Vonog, V.V., Ponomareva, E.A., Takhaveeva, Yu.V., Zhavner, T.V. (2016). Language portfolio as a form of assessment of students' knowledge of engineering specialties in teaching a foreign language. In Professional linguistic education. Materials of the $X$ International Scientific and Practical Conference proceedings. Nizhny Novgorod, 132-136. Available at: https://elibrary.ru/item.asp?id=27436245

Vonog, V.V., Prokhorova, O.A. (2015). Ispolzovanie LMS MOODLE pri obuchenii inostrannomu yazyku $\mathrm{v}$ aspiranture $\mathrm{v}$ ramkakh smeshannogo i distantsionnogo 
obuchenia [The use of LMS MOODLE in teaching foreign language in a post-graduate course in terms of blended and distant education]. In Vestnik KemSU [Bulletin of Kemerovo state university], 2 (62), 27-30.

Vonog, V.V., Yarotskaya, L.V. (2018). Learning individual's development as function of productive assessment. In The Asian EFL Journal, 6 (20), 429-449.

Vonog, V.V., Yarotskaya, L.V. (2017). Pedagogicheskiy control kak sposob razvitiya lichnosti studenta - budushchego inzhenera [The pedagogical control as a way of personality development of the future engineer]. In Vestnik KSPU [Bulletin of Krasnoyarsk state pedagogical university], 2 (40), 56-62.

Yarotskaya, L.V. (2015). Distsiplina "Inostrannii yazik" i professional'noe razvitie lichnosti [Subject "Foreign language" and professional development of a personality]. In Vestnik MSLU [Bulletin of Moscow state linguistic university], 14 (725), 48-55.

Yarotskaya, L.V. (2013). Revisiting the problem of differentiation between C 1 and C 2 levels of the ELP. In Vestnik MSLU [Bulletin of Moscow state linguistic university], 14 (674), 134-138.

Yevdokimova, M.G. (2007). Sistema obucheniya inostrannym yazykam na osnove informatsionno-kommunikativnoi tekhnologii (tekhnicheskii vuz, angliiskii yazyk) [The system of teaching foreign languages based on information-communicative technology (technical higher school, English language)]. (Unpublished doctoral dissertation). Moscow state linguistic university. Moscow.

\section{Европейский языковой портфель как эффективный инструмент контроля обученности иностранному языку}

В.В. Воног

Сибирский федеральнылй университет Россия, 660041, Красноярск, пр. Свободный, 79

Статья посвящена рассмотрению основных функиий и дистрипторов Европейского языкового портфеля (ЕЯП) при обучении профессиональному иностранному языку студентов инженерных специальностей в рамках личностно-ориентированного обучения. Приводится организация контроля результатов усвоения знаний обучающихся. Дается описание структуры ЕЯП и его содержания, обсуждается положительный опыт апробаџии этой технологии в обучении студентов высших учебных заведений. Использование ЕЯП в качестве инноваџионного подхода стало особенно актуальным 
в рамках мероприятий по языковой подготовке студентов инженерных специальностей в соответствии с международной признанной системой повышения конкурентоспособности ведущих российских университетов, реализующейся в Сибирском федеральном университете (Красноярск).

Автор описывает методологическую основу для разработки системь оценки, соответствующей специфике инженерного образования, указывает основные функиии оценки в новом формате и определяет особенности этой деятельности в рамках ЕЯП. В статье рассматривается аргументирование использования Европейского языкового портфеля с акцентом на образовательный продукт обучающегося.

Результаты исследования включают в себя мониторинг достижений, полученньх в прочессе обучения, авторских наблюдений и исследований, основанных на результатах учашихся и направленных на осуществление контроля развития их языковой личности благодаря апробации экспериментальной части языкового портфеля кафедрой иностранных языков для инженерных направлений Института филологии и языковой коммуникации Сибирского федерального университета.

Выводы были подтверждены прогностическим моделированием и экспериментальным обучением. Согласно авторской точке зрения, ЕЯП основывается на приниипах, которые бросают вызов традиционной практике обучения и преподавания и, таким образом, влияют на политику и систему образования. С другой сторонь, апробация языкового портфеля определила перспективный круг вопросов, требующих дальнейшего исследования в рамках инженерного образования.

Ключевые слова: Европейский языковой портфель, оченка, инженерное образование, межкультурная иноязычная профессиональная коммуникативная компетениия, преподавание иностранного языка.

Научная спещиальность: 13.00.08- теория иметодика профессионального образования. 